\title{
Desenvolvimentismo versus liberalismo econômico no período populista e o gasto público social ${ }^{1}$
}

\author{
Julio Manuel Pires ${ }^{2}$
}

\begin{abstract}
Resumo
O artigo propõe-se a examinar o dispêndio público brasileiro na área social durante o período populista (1930-1964), fazendo uma análise comparativa entre os períodos "autoritário" e "democrático". Busca-se também averiguar qual a importância do contexto econômico, político e ideológico para explicar as alterações observadas no gasto social nesse período.
\end{abstract}

Palavras-chave: Política social; Populismo; Desenvolvimento econômico; Educação; Saúde.

\begin{abstract}
Developmentalism versus economic liberalism in the populist period and social public expenditure

This article aims to investigate social public expenditure during the populist period (1930-1964) by carrying out a comparative analysis of the "authoritarian" and "democratic" ages. In addition, the economic, political and ideological context will be investigated in order to clarify the changes in social expenditure that took place in this period.
\end{abstract}

Key words: Social policy; Populism; Economic development; Education; Health.

JEL N36, H51, H52, H55.

\section{Introdução}

Os anos de 1930 e 1964 delimitam dois momentos importantes de inflexão no processo de desenvolvimento econômico, político e social brasileiro. Tais inflexões foram desencadeadas por alterações substantivas no comando do aparato governamental e consolidaram a ascensão e domínio de determinadas forças e coalizões políticas em cada período.

Os relacionamentos diversos estabelecidos entre o Estado e a sociedade a partir de 1930 e, posteriormente, a partir de 1964 permitiram a conformação de políticas econômicas e sociais diversas, definindo padrões alternativos de desenvolvimento econômico no período pré-1930, populista e pós-1964 - ainda que isso não implique atribuir homogeneidade ao interregno 1930/64.

(1) Trabalho recebido em junho de 2008 e aprovado em junho de 2009.

(2) Professor do Departamento de Economia e do Programa de Estudos Pós-Graduados em Economia Política da Pontifícia Universidade Católica (PUC-SP)/Professor do Departamento de Economia da FEARP/USP/Graduação em Economia e História pela Universidade de São Paulo, São Paulo, SP, Brasil. E-mail: jmpires@usp.br. 
A bibliografia na área econômica relativa ao período correspondente à Revolução de 1930 até o final da Segunda Guerra Mundial tem sua preocupação centrada na crise econômica da década de 30, nas respostas da política econômica e da economia a essa crise, na centralização progressiva do poder e dos instrumentos de política econômica, no fortalecimento decisivo do processo de industrialização e nas iniciativas estatais no campo econômico. No tocante à "questão social", o dispêndio público com educação, saúde, previdência social etc. perde qualquer destaque frente à análise da estruturação corporativista das relações de trabalho com a criação do Ministério do Trabalho, Indústria e Comércio e a consolidação da legislação trabalhista.

Assim, o dispêndio público na área social, um dos aspectos fundamentais para o entendimento do evolver da economia e da sociedade brasileira nesse período, alcança reduzida repercussão junto aos pesquisadores do período. $\mathrm{O}$ exame da literatura mostra uma exígua disponibilidade de estudos cuja preocupação primeira seja a política social em conjunto, englobando suas várias áreas (saúde, educação, previdência social). Cabe também peso relativo modestíssimo, nesses trabalhos, ao relacionamento da política social com o contexto político, social e econômico. Tais estudos, geralmente, apresentam uma preocupação particular em centrar a análise no período pós-1964, buscando caracterizar o evolver da política social nos governos militares. ${ }^{3}$ As pesquisas cujo espaço de tempo de análise é mais amplo, ao abranger, outrossim, a quadra anterior à alteração institucional promovida pelos militares, caracterizam-se por constituir estudos setoriais, preocupados com áreas específicas da política social saúde, educação, previdência - e, sobretudo, com a descrição da evolução institucional e sua interface política. ${ }^{4}$

Todavia, a ausência maior fica por conta da análise do padrão público de despesas. Não se encontra qualquer trabalho direcionado para estudar a política social a partir de um exame do dispêndio público nos três níveis de governo.

A política social desempenha papel essencial no âmbito da ideologia de legitimação do capitalismo, ainda que, por vezes, não seja tão prestigiada na composição do orçamento público. O "problema social" e o "interesse governamental em buscar melhores condições de vida para a população", mediante a política social, têm papel destacado na articulação ideológica inerente ao capitalismo. No entanto, o encaminhamento peculiar dado ao debate ideológico

(3). Como exemplos deste tipo de preocupação, ver os trabalhos de Demo (1981), Cignolli (2001) e Abranches (2000).

(4) Como exemplos, podemos citar: Coutinho e Salm (1986), Vieira (1986), Cunha (1975), Bierrenbach (2000), Romanelli (2000), Gonçalves (1982), Malloy (1986), Braga e Paula (1986), Cohn (2001), Mello (1977) e Possas (2001). 
no Brasil das décadas de 1930 a 1960 permitiu que se instituísse retórica diversa quanto à política social.

Havia no período populista uma hegemonia inquestionável das ideias desenvolvimentistas e nacionalistas no debate político. Tais ideias alcançaram ainda maior repercussão no denominado "período democrático-populista" (19461964). Isto permitiu deslocar o eixo fundamental do discurso político da ênfase na política de bem-estar social para um conjunto diferente de proposições nas quais o bem-estar coletivo, ainda entendido como o objetivo mais importante, apareceu como dependente da velocidade do processo de crescimento econômico que a nação pudesse levar adiante. Permitiu-se, desse modo, que, mesmo a nível retórico, as considerações relativas às políticas sociais fossem conduzidas a plano secundário, subordinadas ao "objetivo nacional" de desenvolvimento.

O exame do período como um todo (1930/64) permite atentar para a influência dos contextos políticos diversos - autoritarismo (1930/45) e relativa democracia política (1946/64) - na alocação e gestão de recursos para a área social. Ainda mais especificamente, pode-se proceder a mesma análise em termos de governos inclinados ao liberalismo no campo econômico e repressivo no trato com os movimentos de esquerda, como é o caso do governo Dutra, ou do governo Goulart, no final do período, caracterizados por postura bem diversa.

Assim, o objetivo básico deste trabalho consiste em examinar a intervenção do Estado no período populista relativamente às políticas de saúde, de educação e previdência social. Trata-se também de resgatar o "outro lado" do desenvolvimentismo, buscando esclarecer como se comportou a política social brasileira no período 1930/64, mediante a análise do comportamento do dispêndio público.

Este artigo compõe-se, além desta introdução, de mais três tópicos e das Considerações Finais. Assim, no próximo tópico examinam-se a origem dos dados utilizados, bem como as restrições a que eles se encontram sujeitos. No tópico dois procede-se a uma análise comparativa do dispêndio social e de suas características nos períodos "autoritário" e "democrático" populista para, no tópico três, averiguar em que medida o contexto econômico, político e ideológico influenciou as alterações observadas no dispêndio social. Por fim, nas Considerações finais busca-se sintetizar os resultados obtidos, articulando-os com uma visão mais abrangente a respeito do papel da política social numa economia subdesenvolvida.

\section{Aspectos metodológicos e fontes das informações}

A atuação do governo na denominada área social parece ter sido muito reduzida nos anos circunvizinhos ao início do século. Num documento produzido pelo Centro Industrial do Brasil, a pedido do Ministério da Indústria, Viação e 
Obras Públicas, e concluído em 1907 (Brasil. FIBGE, 1986, p. 249 et seq.), constam como atribuições da União, estados e municípios, dentro da área social, apenas os setores de educação e "saneamento das cidades". No caso da educação havia uma divisão em termos de que aos estados e municípios caberia a organização e manutenção da escola primária, enquanto a União ficaria encarregada da implantação e manutenção das escolas de nível secundário e superior. Já nas demais áreas sociais, como saúde, habitação ou previdência, não se notam quaisquer referências à necessidade de o governo aí intervir. Tal situação resulta dos marcos liberais a delimitar a atuação governamental nesse período, não só no Brasil, mas também na grande maioria dos países ao redor do mundo, os quais não permitiam a presença de tais preocupações nem mesmo em termos retóricos.

A crise de 1929 e a profunda depressão a se estender ao longo da década de 1930 marcaram um ponto de inflexão importante no tocante à relação Estado/economia. A partir daí - ao contrário do que ocorria anteriormente, com o próprio apoio da burguesia, ou pelo menos de frações importantes dela -, o Estado passou a adquirir uma postura mais intervencionista. A crise, portanto, não se verificou apenas no plano econômico, mas se estendeu também para o plano ideológico, deixando em um plano secundário, pelo menos por algumas décadas, a teoria liberal, a qual pregava o livre funcionamento do mercado como a melhor forma de regular a economia. Esta crise ideológica refletiu, no âmbito burguês, na reação fascista e nas teorias corporativistas, e, de outro lado, no fortalecimento da ideologia socialista e da organização dos trabalhadores. O Estado, a partir de então, desenvolveu todo um conjunto novo de instituições e aparatos jurídicos para intervir na economia, dos quais se destacam aqueles destinados à área social.

Uma observação preliminar se faz necessária. A ênfase dada aqui ao exame do volume do dispêndio público não deve nos levar à conclusão - acima de tudo ingênua - de que bastaria uma dotação maior de recursos para alterar substancialmente o quadro na área social para melhor. Aceitar tal proposição significa, por um lado, subestimar a importância de todo o contexto socioeconômico vigente (nível e qualidade do emprego, salário, distribuição de renda etc.) e, por outro, superestimar as "boas intenções" e eficiência do aparato estatal, o qual transformaria automaticamente todo recurso extra em melhores indicadores de qualidade de vida. ${ }^{5}$

Quando se tenciona analisar o gasto público, não há como deixar de observar as limitações a que estão sujeitos os dados do dispêndio do governo

(5). Ver, a este respeito, a crítica de Vianna e Silva (1989, p. 119) aos trabalhos de Jaguaribe et al. (1986, 1989). 
federal em termos dos ministérios; quer dizer, perde-se muito da percepção adequada da situação a respeito das despesas públicas na área social.

A utilização dos dados por ministério como sendo os do gasto em cada área, embora possua algum valor indicativo, revela-se claramente insuficiente. Conforme observa um autor coetâneo:

Se esses ministérios e demais órgãos autônomos abrangessem, efetivamente, todas as atividades que a rigor deveriam desempenhar, quando o orçamento da União consignasse - Despesa do Ministério da Educação e Saúde: 1.000.000.000 de cruzeiros - poder-se-ia deduzir que as despesas do Governo Federal com o serviço de educação e saúde atingiriam a 1.000.000.000 de cruzeiros anuais. Convém acentuar, no entanto, que à conta de outros ministérios correm despesas que dizem respeito à educação e saúde, tais como a de manutenção de serviços clínicos e de hospitalização, de obras de saneamento, de cursos de aperfeiçoamento, de escolas e diversas outras de amparo à cultura, que deveriam ser levadas em consideração quando se quisesse levantar o total das despesas da União com o serviço de educação e saúde (Viana, 1950, p. 237-238). ${ }^{6}$

Em relação aos dados para a União, cuja despesa corresponde, na maioria dos anos, a cerca de metade do total dos gastos do setor público, houve a necessidade, para os anos posteriores a 1944, de sistematização dos dados fornecidos pelo Balanço Geral da União, uma vez que a literatura disponível forneceu apenas resultados parciais para alguns anos e algumas áreas específicas, feitos por autores que se debruçaram sobre o assunto. Para o período 1932/44 é possível encontrar dados acerca dos gastos sociais dos três níveis de governo nos Anuários Estatísticos do Brasil. Tais informações deixaram de ser publicadas a partir do ano final da Segunda Guerra.

Dada a impossibilidade de examinar a totalidade dos anos do período 1945/64, foram analisados todos os itens de despesa constantes dos Balanços Gerais da União dos anos de 1946, 1948, 1950, 1952, 1955, 1957, 1960, 1962 e 1964, independentemente do ministério ou órgão a que estivessem vinculados, para tornar possível aquilatar a real dimensão dos gastos sociais. ${ }^{7}$ Com base nestas informações procede-se a análise constante nas páginas seguintes.

Para um exame mais pormenorizado do orçamento e dispêndio efetivo do governo federal foi utilizada a "Análise da Despesa Orçamentária” que compunha o volume II dos Balanços Gerais da União desde o ano de 1942. Tal volume traz

(6) A inexistência de dados mais específicos para os gastos do governo federal relativamente aos serviços pode ser ilustrada pela observação de outro autor, escrevendo dez anos depois, o qual, pretendendo analisar o dispêndio com saúde pública, é obrigado a se contentar com as informações fornecidas por ministérios: "para as despesas da União, consideramos como sendo relativos ao serviço em foco os gastos com o Ministério da Saúde" (Macedo (1960, p. 17-21).

(7) Para os anos de 1964 em diante, o Ministério da Fazenda promoveu tal sistematização, a qual pode ser encontrada nos vários números da publicação Finanças do Brasil. 
um conteúdo mais rico de informações, fruto de elaboração mais cuidadosa e minuciosa das despesas públicas por parte da Contadoria Geral da República para apresentação ao Tribunal de Contas da União. ${ }^{8}$

A consolidação do dispêndio público social nas três esferas de governo e do sistema previdenciário pode ser visualizada nos gráficos seguintes, construídos a partir dos dados fornecidos pelos Balanços Gerais da União (para a administração direta federal), Anuários Estatísticos do Brasil (sistema previdenciário) e publicações do Conselho Técnico de Economia e Finanças, subordinado ao Ministério da Fazenda (dispêndios estaduais e municipais).

Antes de se avaliar os números e tendências, cabem algumas observações acerca do total acima alocado para o item "previdência social" e "saúde". Relativamente ao setor saúde, se julgou indispensável agregar aos gastos da administração direta (federal, estadual e municipal), os dispêndios com saúde a cargo das Caixas e Institutos de Aposentadoria e Pensões. Não se encontra qualquer justificativa para excluí-los dos gastos sociais totais do setor público apenas pela forma de financiamento e administração diversa que possuem frente aos demais gastos.

No tocante aos gastos com previdência social, encontra-se alguma dificuldade para avaliar o total de despesas da administração direta com este item. No âmbito estadual e municipal as dificuldades apresentadas revelaram-se ainda maiores. Fez-se, então, uso de estimativas baseadas nas informações disponíveis.

Para a maioria dos anos cobertos em nossa pesquisa, pudemos obter, por intermédio dos Anuários Estatísticos do Brasil e da Revista de Finanças Públicas, a porcentagem do orçamento federal comprometida com os inativos e pensionistas. 9 Para a estimativa dos gastos efetivos utilizamos as porcentagens

(8) Conforme regulavam os artigos 113 e 114 do Regulamento Geral de Contabilidade Pública:

"Art. 113 - O desdobramento analítico das verbas da despesa em consignações e subconsignações não fará parte das contas a serem apresentadas ao Congresso, mas será, posteriormente, objeto de exame do Tribunal de Contas, em face das despesas pelo mesmo registradas em cada consignação.

Art. 114 - Para os fins do artigo anterior, a Contadoria Geral da República, dentro de seis meses após a apresentação ao Congresso das contas anuais, remeterá àquele Tribunal todas as tabelas explicativas, por consignações e subconsignações, da despesa em cada verba, segundo o balanço definitivo apresentado" (Brasil. Ministério da Fazenda. Balanço Geral da União, 1960, v. I, p. 25).

(9) As participações relativas dos gastos com inativos e pensionistas no dispêndio total, para os anos em que esta informação encontra-se disponível, são as seguintes:

\begin{tabular}{rccccccccccccc}
\hline Ano & 1937 & 1938 & 1939 & 1940 & 1941 & 1942 & 1943 & 1946 & 1947 & 1948 & 1949 & 1950 & 1951 \\
$\%$ & 3,3 & 3,8 & 3,3 & 4,7 & 5,7 & 4,8 & 5,4 & 4,3 & 6,2 & 5,4 & 5,5 & 5,0 & 5,4 \\
\hline Ano & 1952 & 1953 & 1954 & 1955 & 1956 & 1958 & 1959 & 1960 & 1961 & 1962 & 1963 & 1964 \\
$\%$ & 6,1 & 5,6 & 5,3 & 5,2 & 6,0 & 6,3 & 6,6 & 7,0 & 6,2 & 4,2 & 5,5 & 5,3 \\
\hline
\end{tabular}

Fontes: para os anos de 1946 a 1956: Brasil. Ministério da Fazenda. Revista de Finanças Públicas, jun./jul. 1956, p. 65. Demais anos: Brasil. FIBGE. Anuário Estatístico do Brasil (vários anos). 
alocadas nos orçamentos multiplicando-as pelo dispêndio total efetivo da União. ${ }^{10}$ Para os anos em que as informações não puderam ser obtidas optamos, à falta de critério mais rigoroso, por utilizar a porcentagem referente ao ano mais próximo.

As despesas com inativos dos estados e Distrito Federal apresentam percentuais bem menores. Em 1946 e 1950, os valores registrados nos orçamentos para pagamento de pensões e aposentadorias equivalem a 2,80\% e 3,31\% dos gastos totais, respectivamente. ${ }^{11}$ Estes percentuais encontram-se próximos aos verificados para a década de 30, denotando certa estabilidade do dispêndio com inativos e pensionistas comparativamente ao gasto total. ${ }^{12}$ Assim, para os anos de que se dispunha da informação, foi possível cruzar o percentual orçado com o dispêndio efetivo e, para os demais anos, utilizar-se o percentual médio dos anos em que os dados estavam disponíveis.

Relativamente aos municípios, segundo os dados fornecidos pelo Instituto Brasileiro de Administração Municipal (IBAM), referentes ao ano de $1959,{ }^{13}$ dos cerca de 250.000 servidores públicos municipais, apenas $10 \%$ possuía montepio mantido pelas prefeituras e $21 \%$ participavam de algum tipo de seguro em grupo; os mais de $2 / 3$ restantes não gozavam de qualquer amparo previdenciário. A proporção de prefeituras a manter funcionários nesta última situação varia muito de estado para estado; desde apenas 20,34\% no Rio Grande do Sul até 98,36\% em Sergipe. De modo geral, a porcentagem de municípios localizados no Sul e Sudeste proporcionando algum tipo de previdência aos servidores municipais é maior comparativamente ao restante do país.

Tendo em vista tais informações, a escolha recaiu por desconsiderar os gastos dos municípios com previdência social. A magnitude restrita do dispêndio total dos municípios, juntamente com a ausência do gasto com inativos e pensionistas para a maioria deles, deve fazer com que o viés causado por esta omissão seja pequeno.

Feitas estas observações, pode-se passar, finalmente, à análise dos dados dispostos nos gráficos e tabelas a seguir.

(10) À exceção dos anos de 1940 a 1943, para os quais os dados colhidos referem-se já ao dispêndio efetivo e não orçado como nos demais anos.

(11) Brasil. Ministério da Fazenda. Boletim do Conselho Técnico de Economia e Finanças, fev. 1950, p. 33 .

(12) Para os anos de 1930 a 1939, os percentuais do gasto total fixados pelos estados e Distrito Federal para atender às despesas com inativos e pensionistas são os seguintes:

\begin{tabular}{rcccccccccc}
\hline Anos & 1930 & 1931 & 1932 & 1933 & 1934 & 1935 & 1936 & 1937 & 1938 & 1939 \\
2,0 & 2,2 & 3,5 & 3,1 & 3,3 & 3,0 & 3,4 & 3,3 & 3,9 & 3,3 \\
\hline
\end{tabular}

Fonte: Brasil. FIBGE (1990, p. 128).

(13) Macedo (1961, p. 23-33). 


\section{Os gastos sociais nas fases "autoritária" e "democrática” do populismo}

As informações colhidas a respeito da participação do dispêndio com educação, saúde e previdência social no total do gasto público - administração direta mais sistema previdenciário - estão demonstradas no Gráfico 1.

Gráfico 1

Participação dos gastos com saúde, educação e previdência nos gastos totais Adm. Direta + Sistema previdenciario: 1932-1964

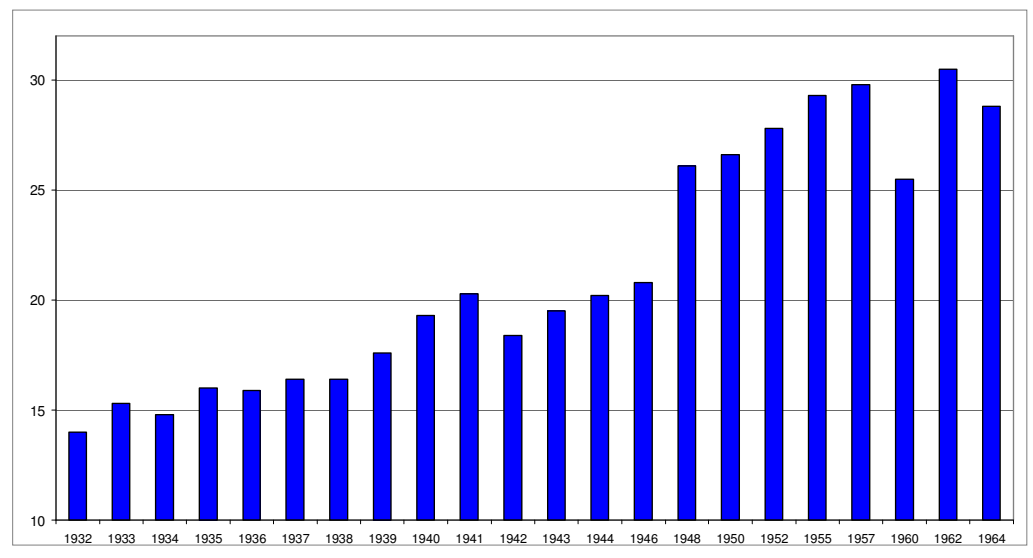

Fontes dos dados primários: Brasil. MF. Balanço Geral da União (Vários anos). MEC (1957, 1958, 1959, 1960). FIBGE. Anuario Estatístico do Brasil (Vários anos); FIBGE (1990, p. 616-617).

A análise deste gráfico não deixa dúvidas a respeito da coincidência entre a mudança de patamar nesse indicador e o processo de redemocratização política.

A proporção do gasto público total com a área social que, anteriormente a 1946, poucas vezes correspondeu a mais de $1 / 5$ (passa do nível de $14 \%$ a $16 \%$ na década de 30 para porcentagens circundantes a $18 \%$ a $20 \%$ no período 1939/46), alçou-se a mais de $26 \%$ a partir de 1948 e, numa tendência ascendente (exceção ao ano de 1960), chegou a alcançar 30,5\% em 1962, para decair em 1964.

Tal incremento tornou-se possível devido à manutenção consistente de altas taxas de crescimento real positivo para a maioria dos anos pesquisados no período 1946/64, próximas a 15\%, conforme mostra o Gráfico 2. Mesmo nos demais anos a taxa ainda manteve-se elevada, ao redor de $7 \%$ em média ao ano anotando-se novamente a exceção de 1960, no qual a variação real apresentou-se negativa. 
Gráfico 2

Despesas com saúde, educação e previdência - Variação real anual Administração Direta + Sistema previdenciario: 1933-1964

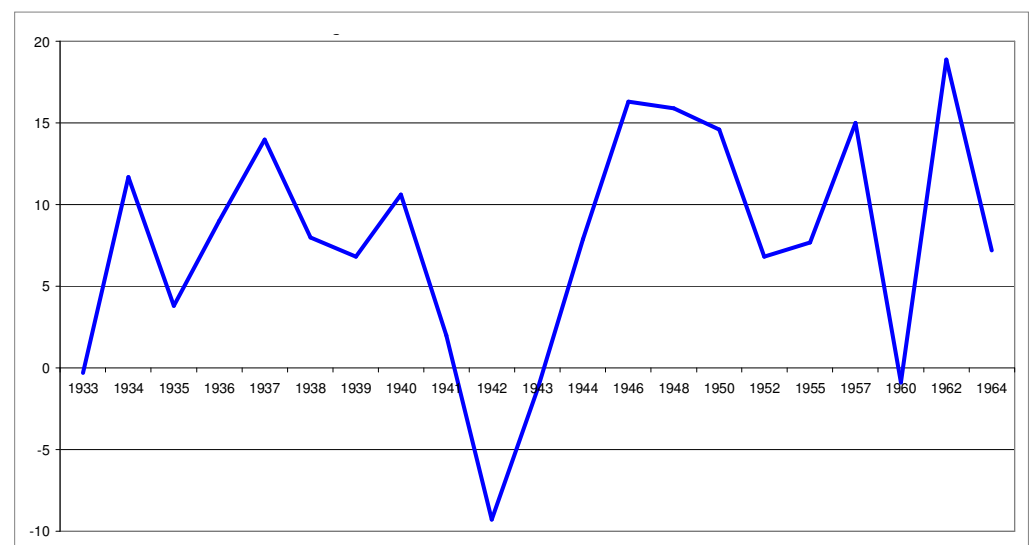

Fontes dos dados primários: Brasil. MF. Balanço Geral da União (Vários anos). MEC (1957, 1958, 1959, 1960). FIBGE. Anuario Estatístico do Brasil (Vários anos); FIBGE (1990, p. 176-177; 226-231).

Isto permitiu ampliar as despesas sociais de forma constante no período 1946/64 como porcentagem do Produto Interno Bruto, conforme revela o gráfico 3 abaixo. Para os anos pesquisados (novamente, com a exceção do ano de 1960), tal proporção passa de 3,7\% do PIB em 1946 para 6,59\% em 1964, ao contrário da tendência de estagnação, com pequeno decréscimo, verificada no conjunto do período anterior.

Gráfico 3

Despesas com saúde, educação e previdência social como \% do PIB

Administração Direta + Sistema previdenciario: 1932-1964

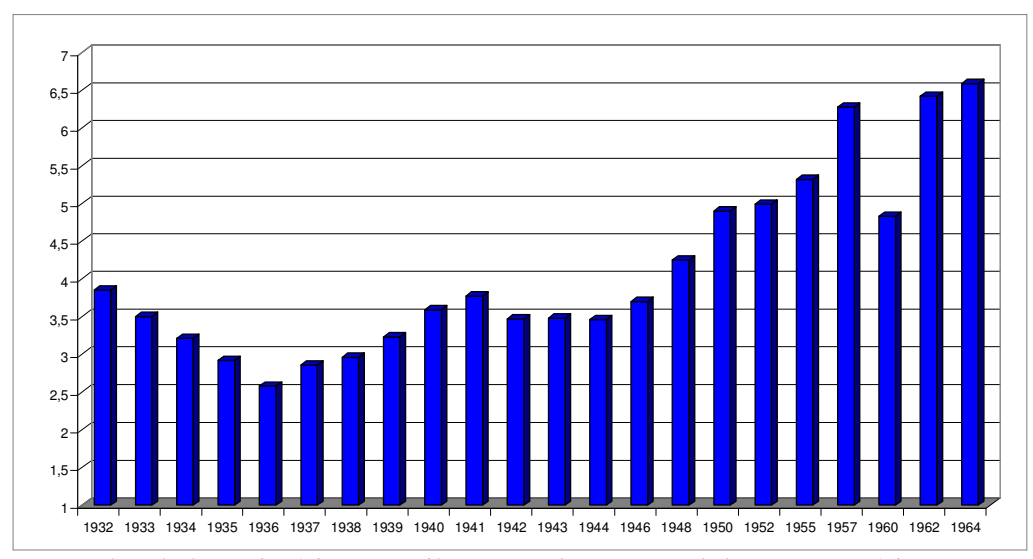

Fontes dos dados primários: Brasil. MF. Balanço Geral da União (Vários anos). MEC (1957, 1958, 1959, 1960). FIBGE (1990, p. 102-103); FIBGE. Anuario Estatístico do Brasil (Vários anos); Contador e Haddad (1975, p. 436-437). 
Entre os anos de 1932 a 1936 operou-se significativa redução (3,85\% para $2,58 \%$ do PIB), coincidente, aliás, com a redução observada para o conjunto da despesa pública. A recuperação do período 1937/41 foi então interrompida neste último ano, mantendo-se os gastos com educação, saúde e previdência social em níveis próximos a 3,5\% do PIB.

Para efeito de comparação, segundo as informações de Gough (1990, p. 238-239), os gastos com seguridade social no Reino Unido elevaram-se de 5,2\% do Produto Nacional Bruto (PNB), em 1937, para 5,3\% em 1951 e 6,7\% em 1961. Para estes mesmos anos, os gastos com saúde e assistência evoluíram de 1,8\% do PNB para $4,5 \%$ e $4,4 \%$, respectivamente. Ao mesmo tempo, os gastos com educação passaram de 2,6\% (1937) para 3,2\% (1951) e, finalmente, alcançaram 4,2\% do PNB em 1961. O total dos gastos sociais no Reino Unido, portanto, teria aumentado de 9,5\% do PNB em 1937 para 13,0\% em 1951, até alcançar 15,3\% em 1961.

A importância de cada área social (saúde, educação e previdência social) no total dos gastos sociais alterou-se significativamente ao longo do período populista, como podemos vislumbrar na Tabela 1, na sequência.

Tabela 1

Despesas com saúde, educação e previdência social

Valor em cruzeiros constantes e participação de cada área no gasto social total: 1932-1964

\begin{tabular}{|c|c|c|c|c|c|c|c|}
\hline \multirow[t]{2}{*}{ Ano } & \multicolumn{2}{|c|}{ Educação } & \multicolumn{2}{|l|}{ Saúde } & \multicolumn{2}{|c|}{ Previdência Social } & \multirow{2}{*}{ Total } \\
\hline & $\begin{array}{l}\text { Valor em } \\
\text { Milhares de } \\
\text { Cr\$ de } 1946\end{array}$ & $\begin{array}{l}\% \text { do } \\
\text { Total }\end{array}$ & $\begin{array}{l}\text { Valor em } \\
\text { Milhares de } \\
\text { Cr\$ de } 1946\end{array}$ & $\begin{array}{l}\% \text { do } \\
\text { Total }\end{array}$ & $\begin{array}{c}\text { Valor em } \\
\text { Milhares de } \\
\text { Cr\$ de } 1946\end{array}$ & $\begin{array}{l}\% \text { do } \\
\text { Total }\end{array}$ & \\
\hline 1932 & $379.670,87$ & 44,09 & $238.032,71$ & 27,64 & $243.418,68$ & 28,27 & $861.122,26$ \\
\hline 1933 & $404.322,40$ & 47,09 & $230.975,57$ & 26,90 & $223.248,65$ & 26,00 & $858.546,62$ \\
\hline 1934 & $434.323,47$ & 44,67 & $270.467,08$ & 27,82 & $267.515,93$ & 27,51 & $972.306,48$ \\
\hline 1935 & $479.959,89$ & 47,49 & $267.790,19$ & 26,50 & $262.963,42$ & 26,02 & $1.010 .713,60$ \\
\hline 1936 & $502.196,38$ & 45,22 & $303.957,79$ & 27,37 & $304.520,12$ & 27,42 & $1.110 .674,29$ \\
\hline 1937 & $567.781,21$ & 43,96 & $373.902,82$ & 28,95 & $349.797,70$ & 27,08 & $1.291 .481,73$ \\
\hline 1938 & $570.371,67$ & 40,63 & $389.910,97$ & 27,78 & $443.501,84$ & 31,59 & $1.403 .784,49$ \\
\hline 1939 & $617.762,17$ & 41,01 & $459.890,64$ & 30,53 & $428.553,56$ & 28,45 & $1.506 .206,53$ \\
\hline 1940 & $659.301,47$ & 39,13 & $488.299,02$ & 28,98 & $537.194,12$ & 31,88 & $1.684 .794,78$ \\
\hline 1941 & $624.564,43$ & 36,33 & $460.925,64$ & 26,81 & $633.688,28$ & 36,86 & $1.719 .178,34$ \\
\hline 1942 & $532.494,65$ & 33,85 & $422.440,66$ & 26,86 & $617.963,30$ & 39,29 & $1.572 .898,76$ \\
\hline 1943 & $490.507,47$ & 31,59 & $400.991,83$ & 25,83 & $661.214,19$ & 42,58 & $1.552 .713,48$ \\
\hline 1944 & $537.714,46$ & 31,89 & $488.826,74$ & 29,00 & $659.358,18$ & 39,11 & $1.685 .899,55$ \\
\hline 1946 & $707.885,34$ & 29,42 & $587.242,89$ & 24,40 & $1.111 .343,57$ & 46,18 & $2.406 .471,81$ \\
\hline 1948 & $1.045 .262,45$ & 32,34 & $761.781,45$ & 23,57 & $1.425 .523,63$ & 44,10 & $3.232 .567,86$ \\
\hline 1950 & $1.449 .147,08$ & 34,13 & $949.582,67$ & 22,37 & $1.846 .652,91$ & 43,50 & $4.245 .383,09$ \\
\hline 1952 & $1.589 .673,43$ & 32,83 & $1.172 .514,97$ & 24,21 & $2.080 .197,44$ & 42,96 & $4.842 .385,84$ \\
\hline 1955 & $1.750 .158,18$ & 28,93 & $1.430 .481,30$ & 23,65 & $2.868 .679,72$ & 47,42 & $6.049 .319,19$ \\
\hline 1957 & $2.302 .347,05$ & 28,78 & $1.633 .248,26$ & 20,42 & $4.064 .629,33$ & 50,81 & $8.000 .224,63$ \\
\hline 1960 & $2.435 .973,12$ & 31,29 & $1.626 .555,41$ & 20,89 & $3.723 .628,26$ & 47,82 & 7.786.156,79 \\
\hline 1962 & $3.505 .352,14$ & 31,85 & $2.086 .635,60$ & 18,96 & $5.415 .465,62$ & 49,20 & $11.007 .453,36$ \\
\hline 1964 & $3.689 .763,76$ & 29,17 & $2.482 .175,78$ & 19,62 & $6.477 .649,75$ & 51,21 & $12.649 .589,29$ \\
\hline
\end{tabular}


A Tabela 1 evidencia que todos os setores tiveram ampliação real de seus dispêndios no interregno 1932-64 como um todo, com maior intensidade no denominado período democrático-populista, ocorrendo crescimentos desproporcionais entre as três áreas.

A predominância dos gastos com educação, acompanhada do equilíbrio entre os dispêndios com saúde e previdência social, característico da década de 30, foi substituído, a partir dos anos 40, pela preeminência dos gastos previdenciários, com a perda de importância relativa das despesas educacionais e de saúde. No caso desta última área, a queda relativa se fez mais intensa, sobretudo a partir da segunda metade da década de 50.

Relativamente à área educacional, a fim de se avaliar com maior propriedade a natureza da evolução dos gastos públicos no período, há informações mais detalhadas a respeito da composição destes para os anos de 1932 a 1937 e 1956 a 1959, conforme apresentado nas Tabelas 2 e 3 a seguir.

Tabela 2

Despesas públicas com educação e cultura Segundo a finalidade: União, Estados e Municípios - 1932/37 (Rs 1:000\$000)

\begin{tabular}{|c|c|c|c|c|c|c|c|}
\hline Ano & $\begin{array}{c}\text { Adm. } \\
\text { central, } \\
\text { Serv } \\
\text { Gerais, } \\
\text { Inst. cult. }\end{array}$ & $\begin{array}{c}\text { Primário } \\
\text { Geral }\end{array}$ & $\begin{array}{c}\text { Secundário } \\
\text { Geral }\end{array}$ & Superior & $\begin{array}{c}\text { Outros } \\
\text { ramos } \\
\text { de ensino }\end{array}$ & $\begin{array}{c}\text { Outras } \\
\text { Despesas }\end{array}$ & Total \\
\hline 1932 & $\begin{array}{l}18.343 \\
(6,1 \%)\end{array}$ & $\begin{array}{l}170.129 \\
(56,3 \%)\end{array}$ & $\begin{array}{l}11.865 \\
(3,9 \%)\end{array}$ & $\begin{array}{l}22.529 \\
(7,5 \%)\end{array}$ & $\begin{array}{c}68.329 \\
(22,6 \%)\end{array}$ & $\begin{array}{c}10.837 \\
(3,6 \%)\end{array}$ & 302.033 \\
\hline $1933^{*}$ & $\begin{array}{l}24.092 \\
(7,3 \%)\end{array}$ & $\begin{array}{l}173.616 \\
(52,5 \%)\end{array}$ & $\begin{array}{l}13.282 \\
(4,0 \%)\end{array}$ & $\begin{array}{l}27.489 \\
(8,3 \%)\end{array}$ & $\begin{array}{c}78.200 \\
(23,6 \%)\end{array}$ & $\begin{array}{r}14.200 \\
(4,3 \%)\end{array}$ & 330.879 \\
\hline 1934 & $\begin{array}{l}16.922 \\
(5,0 \%)\end{array}$ & $\begin{array}{l}200.451 \\
(59,1 \%)\end{array}$ & $\begin{array}{c}14.627 \\
(4,3 \%)\end{array}$ & $\begin{array}{c}19.437 \\
(5,7 \%)\end{array}$ & $\begin{array}{c}72.539 \\
(21,4 \%)\end{array}$ & $\begin{array}{r}14.950 \\
(4,4 \%)\end{array}$ & 338.925 \\
\hline 1935 & $\begin{array}{l}26.546 \\
(6,5 \%)\end{array}$ & $\begin{array}{l}222.067 \\
(54,1 \%)\end{array}$ & $\begin{array}{l}22.378 \\
(5,5 \%)\end{array}$ & $\begin{array}{l}29.753 \\
(7,3 \%)\end{array}$ & $\begin{array}{c}91.047 \\
(22,2 \%)\end{array}$ & $\begin{array}{r}18.396 \\
(4,5 \%)\end{array}$ & 410.215 \\
\hline 1936 & $\begin{array}{l}33.416 \\
(7,8 \%)\end{array}$ & $\begin{array}{l}234.474 \\
(54,8 \%)\end{array}$ & $\begin{array}{l}27.258 \\
(6,4 \%)\end{array}$ & $\begin{array}{c}55.563 \\
(13,0 \%)\end{array}$ & $\begin{array}{c}52.513 \\
(12,3 \%)\end{array}$ & $\begin{array}{l}24.922 \\
(5,8 \%)\end{array}$ & 428.146 \\
\hline 1937 & $\begin{array}{c}64.266 \\
(12,2 \%)\end{array}$ & $\begin{array}{l}272.046 \\
(51,8 \%)\end{array}$ & $\begin{array}{l}32.504 \\
(6,2 \%)\end{array}$ & $\begin{array}{c}62.933 \\
(12,0 \%)\end{array}$ & $\begin{array}{c}66.176 \\
(12,6 \%)\end{array}$ & $\begin{array}{l}26.823 \\
(5,1 \%)\end{array}$ & 524.748 \\
\hline
\end{tabular}

* As despesas federais dos anos de 1933 e 1934 referem-se, respectivamente, a exercícios de 15 e 9 meses.

Fontes: Brasil. FIBGE (1940, p. 238). e Brasil. FIBGE. Anuário Estatístico do Brasil (vários anos). 
Tabela 3

Despesas públicas com o ensino e a cultura, segundo o destino:

União, Estados, Distrito Federal e Municípios - 1956/59

$(\operatorname{cr} \$ 1.000)$

\begin{tabular}{lcrrr}
\hline \multicolumn{5}{c}{ Ano } \\
Destino & 1956 & 1957 & 1958 & 1959 \\
\hline $\begin{array}{l}\text { Despesas de Manutenção } \\
\text { Administração superior }\end{array}$ & $1.459 .977(9,2 \%)$ & $1.784 .225(8,6 \%)$ & $2.886 .585(12,8 \%)$ & $3.300 .789(8,7 \%)$ \\
Com estabelecimentos & & & & \\
de ensino & & & & \\
$\quad$ Elementar & $5.723 .559(36,2 \%)$ & $7.229 .411(34,9 \%)$ & $10.876 .279(35,5 \%)$ & $12.982 .139(34,2 \%)$ \\
Médio & $2.508 .241(15,8 \%)$ & $3.754 .880(18,1 \%)$ & $5.952 .449(19,4 \%)$ & $6.767 .385(17,8 \%)$ \\
Superior & $995.733(6,3 \%)$ & $1.657 .070(8,0 \%)$ & $2.473 .879(8,1 \%)$ & $3.712 .951(9,8 \%)$ \\
Não especificados & $83.513(0,5 \%)$ & $16.378(0,1 \%)$ & $40.575(0,1 \%)$ & $98.115(0,3 \%)$ \\
Órgãos e instituiçães culturais & $609.924(3,9 \%)$ & $1.077 .938(5,2 \%)$ & $1.334 .482(4,4 \%)$ & $1.832 .437(4,8 \%)$ \\
Serviços de inspeção & $135.750(0,9 \%)$ & $271.075(1,3 \%)$ & $390.561(1,3 \%)$ & $451.126(1,2 \%)$ \\
Serviços técnicos especializados $736.992(4,7 \%)$ & $77.794(0,4 \%)$ & $157.553(0,5 \%)$ & $189.810(0,5 \%)$ \\
Outras despesas & $507.737(3,2 \%)$ & $422.329(2,0 \%)$ & $748.734(2,4 \%)$ & $1.010 .907(2,7 \%)$ \\
$\quad$ Total & $12.761 .426(80,6 \%)$ & $6.291 .100(78,5 \%)$ & $24.861 .097(81,2 \%)$ & $30.345 .659(79,9 \%)$
\end{tabular}

Subvenções e auxílios

Com estabelecimentos

de ensino

$\begin{array}{lllll}\text { elementar } & 60.330(0,4 \%) & 402.380(1,9 \%) & 434.415(1,4 \%) & 541.591(1,4 \%)\end{array}$

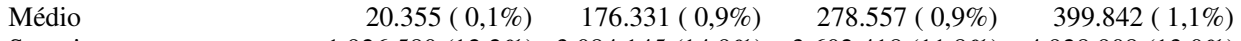

$\begin{array}{lllll}\text { Superior } & 1.926 .580(12,2 \%) & 3.084 .145(14,9 \%) & 3.602 .418(11,8 \%) & 4.928 .908(13,0 \%)\end{array}$

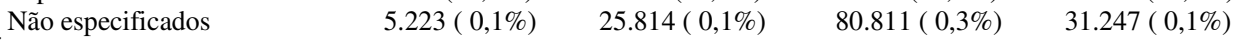

Órgãos e instituições culturais $\quad 475.485(3,0 \%) \quad 163.063(0,8 \%) \quad 350.928(1,1 \%) \quad 481.878(1,4 \%)$

$\begin{array}{lllll}\text { Outras despesas } & 578.575(3,7 \%) & 600.666(2,9 \%) & 1.017 .821(3,3 \%) & 1.242 .077(3,3 \%)\end{array}$

$\begin{array}{lllll}\text { Total } & 3.066 .549(19,4 \%) & 4.452 .399(21,5 \%) & 5.764 .950(18,8 \%) & 7.625 .543(20,1 \%)\end{array}$

Total geral $\quad 15.827 .975$ (100\%) $\quad 20.743 .499$ (100\%) 30.626 .047 (100\%) 37.971 .202 ( $100 \%)$

Fonte: Brasil. Ministério da Educação e Cultura (1957, 1958, 1959 e 1960).

Em termos gerais, as informações mais relevantes prestadas pelas tabelas acima dispostas referem-se à perda de importância do ensino primário no total dos gastos públicos com educação: de mais da metade na década de 30, contraíram-se a cerca de 1/3 nos anos 1950. Isto ocorreu em favor do ensino superior. A participação dos gastos com o ensino universitário, no total das despesas com educação, apresentou uma tendência de crescimento constante. Tal tendência - já presente nos anos 1930, quando passou de cerca de $7 \%$ na primeira metade para $12 \% / 13 \%$ na segunda metade da década - atingiu o patamar de $30 \%$ na segunda metade da década de 50 .

O ensino médio, correspondente aos gastos com o "secundário geral" e maior parcela dos dispêndios com "outros ramos de ensino", perdeu significativa fatia de recursos entre as duas metades da década de 1930, se mantendo, daí por diante e para os anos de que se dispõe de informações, na mesma proporção de cerca de $1 / 5$ das despesas totais com educação.

Todavia, a modificação mais relevante no que se refere à composição das despesas com o ensino foi o acréscimo substancial da participação das subvenções e auxílios. Representada no primeiro interregno, sobretudo pelo item "outras 
despesas", a proporção dos gastos com subsídios para o setor privado viu sua parcela ascender de 5\%/6\% dos gastos totais para cerca de $1 / 5$ do gasto total. Tal fato se encontra intimamente relacionado ao ascenso da importância do ensino superior no conjunto do orçamento público.

Portanto, no que diz respeito ao gasto educacional, há que se relativizar seu impacto redistributivo, tendo em vista a maior ampliação relativa do dispêndio com o ensino superior.

A composição dos gastos por instâncias governamentais, ilustrada no Gráfico 4, mostra inequivocamente que, a par do decréscimo constante da participação da administração direta (União, estados e Distrito Federal e municípios), promoveu-se ininterrupto e substancial aumento da participação do sistema previdenciário no gasto social total: de 7,4\% em 1932 para 46,2\% em 1964.

Gráfico 4

Despesas com saúde, educação e previdência social

Participação relativa no financiamento das despesas sociais: 1932-1964

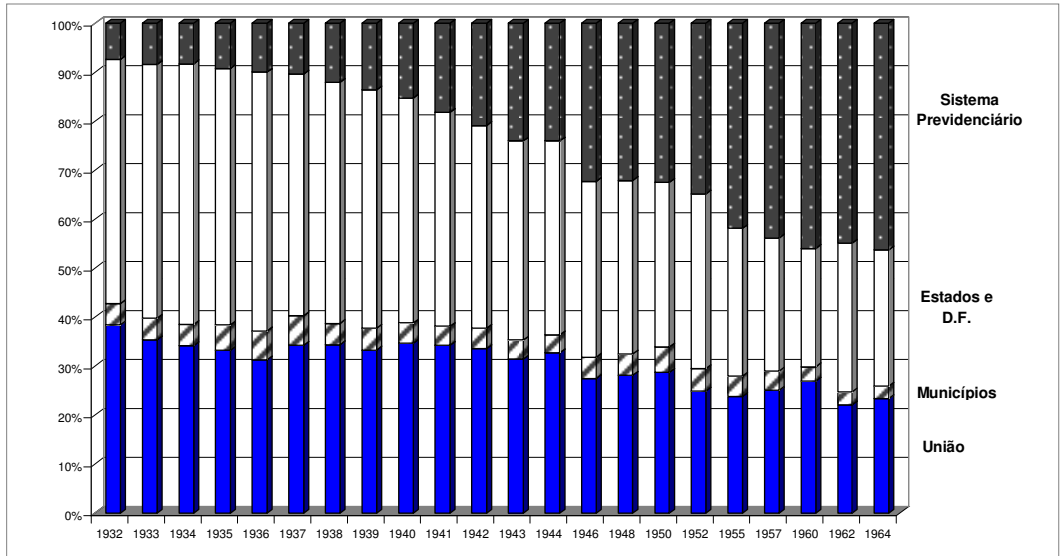

Fonte dos dados primários: Brasil. MF. Balanço Geral da União (Vários anos); MEC (1957, 1958, 1959 e 1960); FIBGE. Anuario Estatístico do Brasil (Vários anos).

As autarquias previdenciárias, portanto, adquiriram, consistentemente, cada vez maior importância no conjunto da política social brasileira. Ao final do período de análise, se apresentavam como responsáveis por quase metade do dispêndio social. Se se tomar em conta seu caráter seletivo - uma vez que a abrangência destas entidades se restringia a parcela diminuta da população total -, torna-se inescapável a conclusão a respeito do acirramento do conteúdo discriminatório da política social brasileira durante o período populista. 
Tendo em vista a enorme importância assumida pelo dispêndio do sistema previdenciário no conjunto do gasto público social, sobretudo após a Segunda Guerra Mundial, cabe avaliar em que medida a exclusão de tais despesas associadas às Caixas e Institutos de Aposentadorias e Pensões permitiria manter a assertiva inicial a respeito do incremento substancial dos gastos sociais totais no período. Tal discriminação se revela importante pelo fato de que os dispêndios das Caixas e Institutos podem não representar necessariamente políticas do governo corrente. $^{14}$

Gráfico 5

Gasto social total: União, Estados e Municípios: 1932-1964

(Excluindo o Sistema previdenciário)

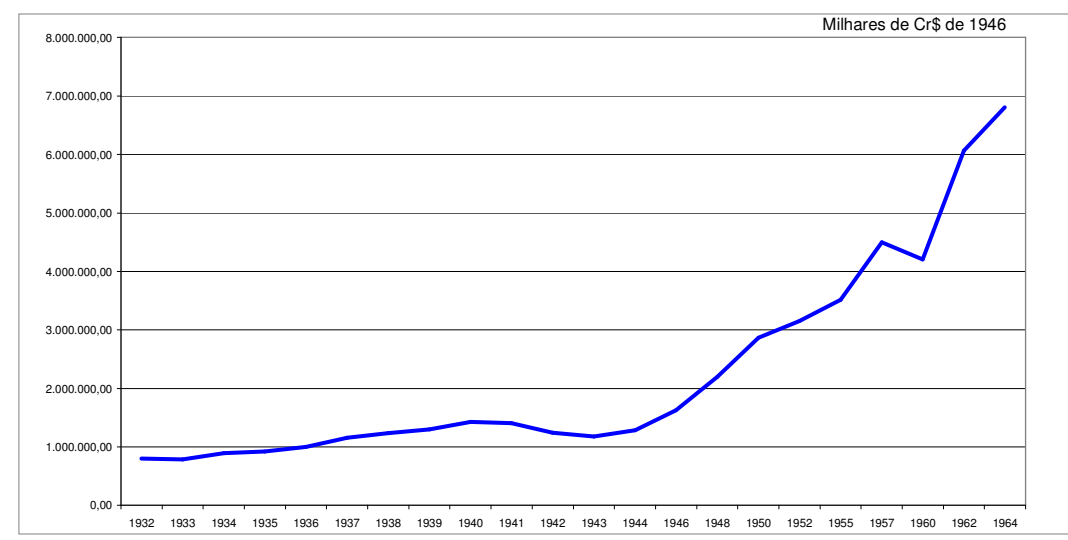

Fontes dos dados primários: Brasil. MF. Balanço Geral da União (Vários anos);

MEC (1957, 1958, 1959 e 1960); FIBGE. Anuario Estatístico do Brasil.

Conforme fica evidenciado no Gráfico 5 acima, mesmo excluindo o sistema previdenciário na contabilização do dispêndio social total, a expansão é bem mais acentuada no período pós-guerra do que durante o Primeiro Governo Vargas; as taxas anuais de crescimento geométrico médio mais do que duplicam de um período para o outro: 4,1\% entre 1932 e 1944, e 8,3\% entre 1946 e 1964.

Se se excluir o sistema previdenciário e se proceder ao exame do ocorrido com a composição do gasto social total entre as três esferas da administração direta (Tabela 4), se verifica que houve, para o conjunto do período, uma certa estabilidade na participação de cada esfera governamental no total da despesa social, com leve tendência de acréscimo da importância da União, em detrimento dos municípios, estados e Distrito Federal.

(14) Para uma análise detalhada da evolução, papel e estatísticas das Caixas e Institutos de Aposentadoria e Pensões, ver especialmente Oliveira e Teixeira (1986). 
Desenvolvimentismo versus liberalismo econômico no período populista e o gasto público social

Tabela 4

Despesas com saúde, educação e previdência social

Participação relativa dos três níveis de governo: 1932-1964

\begin{tabular}{|c|c|c|c|}
\hline Ano & União & Estados e DF & Municípios \\
\hline 1932 & $41,4 \%$ & $53,8 \%$ & $4,8 \%$ \\
\hline 1933 & $38,6 \%$ & $56,5 \%$ & $4,9 \%$ \\
\hline 1934 & $37,2 \%$ & $58,0 \%$ & $4,8 \%$ \\
\hline 1935 & $36,6 \%$ & $57,6 \%$ & $5,8 \%$ \\
\hline 1936 & $34,8 \%$ & $58,6 \%$ & $6,6 \%$ \\
\hline 1937 & $38,3 \%$ & $55,0 \%$ & $6,7 \%$ \\
\hline 1938 & $39,1 \%$ & $56,0 \%$ & $4,9 \%$ \\
\hline 1939 & $38,6 \%$ & $56,3 \%$ & $5,1 \%$ \\
\hline 1940 & $41,0 \%$ & $54,2 \%$ & $4,8 \%$ \\
\hline 1941 & $42,0 \%$ & $53,4 \%$ & $4,6 \%$ \\
\hline 1942 & $42,5 \%$ & $52,2 \%$ & $5,3 \%$ \\
\hline 1943 & $41,5 \%$ & $53,5 \%$ & $5,0 \%$ \\
\hline 1944 & $43,1 \%$ & $52,0 \%$ & $4,9 \%$ \\
\hline 1946 & $40,6 \%$ & $53,0 \%$ & $6,4 \%$ \\
\hline 1948 & $41,5 \%$ & $52,2 \%$ & $6,3 \%$ \\
\hline 1950 & $42,6 \%$ & $49,7 \%$ & $7,6 \%$ \\
\hline 1952 & $38,2 \%$ & $54,7 \%$ & $7,1 \%$ \\
\hline 1955 & $40,9 \%$ & $51,8 \%$ & $7,3 \%$ \\
\hline 1957 & $44,6 \%$ & $48,5 \%$ & $6,9 \%$ \\
\hline 1960 & $49,9 \%$ & $44,8 \%$ & $5,3 \%$ \\
\hline 1962 & $40,1 \%$ & $55,2 \%$ & $4,7 \%$ \\
\hline 1964 & $43,4 \%$ & $51,7 \%$ & $4,9 \%$ \\
\hline
\end{tabular}

Fontes: Dados primários: Brasil. MF. Balanço Geral da União (Vários anos); MEC (1957, 1958, 1959 e 1960); FIBGE. Anuário Estatístico do Brasil (Vários anos).

Entrementes, este último nível de governo, ainda assim, manteve-se como o mais importante, responsabilizando-se, em quase todos os anos pesquisados, por mais da metade do gasto social total da administração direta.

Revela-se, portanto, inequívoco o crescimento significativo do gasto social, seja como porcentagem do gasto total do setor público, seja como proporção do produto interno bruto, entre o período "autoritário" e "democrático" do populismo. Tentemos encontrar as razões para isso.

Para o período populista como um todo, a inflexão verificada a partir de 1946 baseia-se fundamentalmente na maior abertura do sistema político. A mudança qualitativa do processo político, ocorrida a partir da queda de Vargas, teve um reflexo direto na política social. A maior abertura do sistema político, conquanto haja propiciado parcos resultados em termos de demandas universalistas no tocante à política social, permitiu que a mera existência da 
competição eleitoral entre grupos de interesses distintos alterasse significativamente o comportamento do gasto público na área social.

Assim, conquanto condicionadas e limitadas pelo caráter mais geral do contexto político populista, as reivindicações dos grupos dominados adquiriram, notadamente durante a fase democrática do populismo, condições de influir mais decisivamente no processo político, conforme assinala Ianni (1978, p. 17):

Entre 1945 e 1964 entram em cena, em escala bem maior que antes, as massas assalariadas em geral. A partir do Golpe de Estado contra Getúlio Vargas e o Estado Novo, em 29 de outubro de 1945, o processo político brasileiro abrange amplamente os operários, os setores médios da sociedade e grupos de trabalhadores agrícolas. Isto significa que entram em jogo as aspirações de bem-estar social de um proletariado cada vez mais numeroso, ao lado de uma classe média numericamente crescente.

Uma das facetas de que se revestiu tal influência pode ser vislumbrada na maior sensibilidade do orçamento público ao dispêndio social.

Os gastos sociais atendiam, dessa forma, a dois objetivos bem determinados do ponto de vista da classe dominante. De um ponto de vista mais amplo, significavam cobrir, pelo menos em parte, o déficit de legitimidade próprio ao sistema capitalista. Sob um ângulo mais pragmático e concreto, a despesa social aparece como um dos instrumentos utilizados pela fração de classe no poder - seja na esfera federal, estadual ou municipal - para fazer frente às outras frações na competição eleitoral.

\section{Liberalismo, intervencionismo e política social}

Todavia, o evolver do gasto social no período populista apresenta ainda outra particularidade merecedora de análise mais cuidadosa: trata-se da concentração maior das taxas positivas de incremento da despesa social durante o Governo Dutra vis-à-vis qualquer um dos outros interregnos governamentais. Tal constatação adquire maior interesse quando se observa se tratar de um governo cujo conservadorismo em termos políticos e da política econômica (ao menos até a crise cambial de 1947) é inconteste. Pois bem, durante o Governo Dutra, cuja retórica liberal e postura agressiva frente aos movimentos de esquerda não escapa a nenhum dos analistas do período, o dispêndio com a área social cresceu mais aceleradamente.

Para o conjunto do gasto social (saúde, educação e previdência social), nos três níveis de governo mais o sistema previdenciário, as taxas anuais médias (geométricas) de acréscimo nos períodos 1932/44, 1944/50, 1950/55, 1955/60 e $1960 / 64$ correspondem a $5,0 \%, 15,6 \%, 7,3 \%, 5,2 \%$ e $12,9 \%$, respectivamente. Se 
considerarmos apenas o período 1946/50, a taxa média se reduz levemente, atingindo ainda o elevado índice de $15,2 \% .^{15}$

Para os gastos sociais apenas da União, a vantagem do Governo Dutra torna-se mais evidente. No quadriênio 1946/50 os gastos reais do Governo Federal com saúde, educação e previdência social expandiram-se, em média, 16,6\% ao ano (13,1\% se considerado o período $1944 / 50)$, contra $4,0 \%, 3,3 \%, 7,8 \%$ e $8,9 \%$ nos interregnos 1930/46, 1950/55, 1955/60 e 1960/64, respectivamente.

$\mathrm{O}$ resultado, portanto, se revela, de qualquer ângulo que se procure observar, largamente favorável ao governo Dutra em termos da ampliação do gasto público com a área social.

É importante frisar, no entanto, que este aumento do dispêndio social não significa, de forma alguma, a adoção de uma postura mais favorável do Governo Dutra no tocante à melhoria da distribuição de renda. As medidas tomadas relativamente às relações capital-trabalho e ao salário mínimo apontam em sentido inverso. Como já anotado acima, a repressão ao movimento sindical e de esquerda, notadamente a partir de 1947, foi intensa,

com a colocação do PCB na ilegalidade e com a intervenção do Ministério do Trabalho nos principais sindicatos do Rio, de São Paulo e, possivelmente, de outros centros industriais, que se presumia fossem dirigidos por comunistas. A perda da autonomia sindical acarretou forte redução nos movimentos reivindicatórios, o que permitiu ao governo impor um semicongelamento dos salários, apesar do aumento representado pela concessão do descanso semanal remunerado em 1949 (SINGER, 1989, p. 33).

No tocante ao salário mínimo, as evidências são da mesma forma inequívocas; durante os cinco anos de seu mandato, não houve qualquer reajuste, fazendo com que seu poder de compra declinasse substancialmente nesse período. ${ }^{16}$

Tais fatos evidenciam ainda mais a necessidade de buscar uma explicação para a elevação do gasto público social durante o Governo Dutra.

Uma primeira explicação poderia assentar seu peso sobre a diminuta "base de cálculo" encontrada no início deste governo, somada à descompressão repentina das demandas populares propiciada pela redemocratização. Tal resposta, conquanto correta - apontando na mesma direção acima mencionada -, parece insuficiente. Uma resposta alternativa envolve a referência ao contexto mais amplo do desenvolvimentismo.

(15) Para o período 1932/46, a taxa média anual de crescimento é de 6,6\%.

(16) Segundo dados do Ipeadata, entre janeiro de 1946 e janeiro de 1951, o salário mínimo real sofreu uma perda de $41 \%$. 
Com a derrubada de Vargas, as forças políticas interessadas no intervencionismo estatal sofreram sério abalo. Os liberais, congregados sobretudo ao redor da UDN, pareciam ter saído vencedores. Apesar da derrota de Eduardo Gomes para o Ministro da Guerra de Getúlio, o vencedor formou um governo de coalizão com o principal partido de oposição. Mesmo a política econômica, ao menos nos anos iniciais de governo, guiou-se essencialmente pelo figurino liberal.

O clima nos anos seguintes ao final da Segunda Guerra era francamente liberal e não poderia ter deixado de contaminar o Brasil. Ainda que, aqui chegando, se metamorfoseie num liberalismo adjetivado, "brasileiro" - sujeito, por conseguinte, a inúmeras restrições inimagináveis em outros países, como as referentes à manutenção do corporativismo e dirigismo da estrutura sindical. ${ }^{17}$ Todavia, ainda assim, alguns resultados positivos parecem haver decorrido diretamente desse breve predomínio liberal.

Havia toda uma preocupação com os rumos que poderia tomar a economia e a sociedade brasileira nesse momento. Tal situação condicionava o empresariado a pensar em algumas alternativas reformistas, à semelhança das notícias a chegar da Europa. Tais intuitos reformistas viam-se limitados pelas peculiaridades de uma economia pobre e pelo nível de concessões que os empresários pretendem efetivamente fazer, quando instados a converterem o discurso à prática.

A expressão passou a ser combate ao pauperismo na Carta de Teresópolis, onde esse combate estava igualmente associado à ideia de planejamento, mas era apresentado numa forma abstrata e indefinida, como convinha à média dos presentes ao Congresso. Era quase como se, em termos das intenções, se objetivasse tender ao Welfare State do tipo que se anunciava nas notícias que chegavam da Inglaterra de Lasky, só que sem correr os riscos das democracias europeias avançadas (Bielschowsky, 2000, p. 352).

Havia, dessa forma, toda uma retórica liberal - temporariamente hegemônica -, claramente favorável a alguma ampliação do gasto social do governo, como mandava o figurino liberal e que propugnava, simultaneamente, menor interferência do Estado na esfera produtiva.

A preocupação com o desenvolvimento econômico tomava, a partir da década de 50, ênfase diversa, passando a subordinar com maior intensidade o conjunto da política pública aos requisitos do crescimento acelerado. $\mathrm{O}$ perfil de

(17) João Almino (1980, p. 353) exprimiu com extrema pertinência esta característica particular dos "democratas autoritários" brasileiros: "Aqui antifascista pouco tinha que ver com anticorporativista; "liberaldemocrata' assumia também um sentindo distinto daquele que se veiculava na Europa. Acenar para uma estrutura de controle sobre a classe operária através da linguagem corporativista certamente teria parecido escandaloso em 1946 em países como a França e a Itália, em que a luta interna contra o fascismo pôs às claras a doutrina filosófica que estava sendo combatida e gerou uma discussão sobre a mesma. No Brasil a luta contra os fascistas ou tinha um sentido vago ou era associada à guerra contra os países fascistas da Europa e o Japão. A grande discussão política não chegou a se centrar na questão do corporativismo (....". 
intervenção do Estado na economia modificava-se no sentido de comprometer-se mais decididamente com os esforços de investimento necessários para viabilizar uma economia industrial avançada, seja diretamente mediante investimentos do setor público, seja por meio da ampliação dos empréstimos fornecidos ao setor privado pelo BNDE (criado em 1952) ou pelo Banco do Brasil. ${ }^{18}$

O incremento da produção industrial, que até a Segunda Guerra Mundial se concentrava fundamentalmente nos setores de bens de consumo não-duráveis, passava, doravante, a se estender a novos setores, até então em fase embrionária ou inexistentes no Brasil. Entretanto, para que isto fosse possível, novos problemas teriam que ser resolvidos. Os setores acima citados, cuja acumulação fazia-se gradativamente, sem interferência direta do Estado, conquanto seja discutível a intencionalidade das medidas protecionistas, cedeu lugar, em seu papel dinâmico, à indústria de bens de consumo duráveis, bens intermediários e bens de capital.

Estes setores exigiam uma participação bem mais incisiva das autoridades governamentais, caso se quisesse acelerar sua implementação. A ocupação dos novos setores não pôde ser realizada pelos industriais já instalados, tendo em vista que o montante de capital e o conhecimento técnico requeridos se encontravam muito além das possibilidades financeiras e tecnológicas das empresas nacionais. Assim, ao contrário do que ocorreu na Europa e Estados Unidos, o Estado se viu obrigado a intervir diretamente. Naqueles países, o processo de constituição do $D 1$ ocorreu em momento inicial do processo de desenvolvimento das forças produtivas que exigia menor montante de capital para ser implementado. Afora isso, havia o problema tecnológico; o desconhecimento do know-how também se constituía como sério empecilho. A conveniência da intervenção estatal, seja mediante o planejamento, seja por meio da produção direta do Estado de alguns bens, constituiu a tônica do debate a se travar entre neoliberais e desenvolvimentistas ao longo das duas décadas subsequentes ao término da Segunda Guerra Mundial.

Entre o período governamental de Dutra e o Segundo Governo Vargas operou-se substancial alteração na natureza da intervenção do Estado na economia. Para tanto contribuíram, de um lado, a própria personalidade e convicções do novo chefe de Estado (o qual havia dirigido o país durante o conturbado período 1930/45) e, de outro lado, fatores de ordem mais ampla,

(18) As alterações no volume e na composição dos empréstimos do Banco do Brasil, com a maior importância assumida pelos empréstimos ao setor privado no início da década de 50, podem ser constatadas pelos dados e análise de Vianna (1987, p. 74-80). 
relacionados ao "desencanto" com o liberalismo (em termos mundiais) e as deficiências cada vez mais agudas da infraestrutura econômica do país. ${ }^{19}$

\section{Em relação ao contexto internacional, temos que}

a ilusão de uma rápida reorganização liberal do mundo, a partir dos resultados da Conferência de Bretton Woods - existentes no imediato pós-guerra e responsável em larga medida, pelo diagnóstico da realidade e pelas políticas então adotadas pelo Governo Dutra -, havia sido superada, internacionalmente, por uma compreensão mais realista dos problemas da economia mundial (Vianna, 1987, p. 119).

No front interno, as perspectivas de continuidade do processo de desenvolvimento econômico encontravam-se fortemente comprometidas pela existência de diversos pontos de estrangulamento em setores-chave da economia.

O Governo Dutra revelou-se incapaz de articular qualquer pacote de investimento mais consequente visando a sanar as deficiências crônicas já existentes em termos do capital social básico, agravando ainda mais o quadro de carências. ${ }^{20}$ Mesmo iniciativas tímidas como o Plano SALTE mostraram-se completamente ineficazes, dada a inexistência de formas de financiamento definidas. Aprovado apenas em 1950, no último ano do Governo Dutra, foi abandonado no ano seguinte. ${ }^{21}$

(19) Em relação a estes pontos veja-se, especialmente: Draibe (1985, cap. 3); Vianna (1987, cap. 1 e 2); e Fonseca (1989, cap. 6).

(20) "O balanço da administração Dutra em relação às exigências de ampliação do capital social básico aponta para a configuração de um profundo desequilíbrio na capacidade de atendimento dos serviços públicos e de crônicos pontos de estrangulamento da industrialização brasileira" (Lima, 1989, p. 53).

(21) Em sua versão original, o Plano SALTE previa os seguintes itens de despesa:

Resumo financeiro do Plano SALTE (1949-1953)

(Cr\$ milhões e participação relativa)

I - Setores do Plano

1) Setor de Saúde.......... $2.601(13,84 \%)$

2) Setor de Alimentos...... $2.700(14,36 \%)$

3) Setor de Transportes.... $9.655(51,36 \%)$

4) Setor de Energia......... $\quad 2.245(11,94 \%)$

Subtotal I.......... $17.201(91,49 \%)$

II - Verbas gerais

1) Fundo Rotativo............ $800(4,26 \%)$

2) Fundo de Reserva....... $\quad 779(4,14 \%)$

Subtotal II........ $1.579(8,40 \%)$

Total geral..18.800 $(100,0 \%)$

O Plano SALTE resultou de uma junção das recomendações expressas no relatório entregue ao governo pela 1a Comissão Mista Brasil-Estados Unidos (também conhecida como Comissão Abbink) e levantamentos realizados por alguns ministérios e pelo DASP (Cf. CARONE, 1985, p. 77). O processo de desmoralização do Plano foi bastante rápido, apontando-se de forma praticamente unânime, na literatura, a sua pouca efetividade. 
A vitória do desenvolvimentismo significava a predominância de novo conjunto de ideias com conteúdo bastante diverso relativamente à composição do dispêndio público. O papel do Estado na área social deveria ser deixado num plano secundário em favor de uma política mais intervencionista na economia - seja por intermédio de investimentos diretos, seja mediante subsídios e incentivos fiscais ao setor privado. ${ }^{22}$

A título de exemplo e como um cotejo que se afigura interessante, tem-se o volume de recursos carreado para o Banco Nacional de Desenvolvimento Econômico a partir de 1952 e os gastos do governo federal com educação e saúde.

O BNDE, criado em junho de 1952, tinha como maior fonte de recursos no período 1952/61 (com exceção do ano de 1954) o Fundo de Reaparelhamento Econômico, constituído de um adicional de imposto de renda sobre pessoas físicas e jurídicas e sobre reservas e lucros em suspenso ou não distribuídos. Este adicional foi cobrado sob a forma de um empréstimo compulsório restituível depois de 5 anos, durante os quais recebia remuneração de $5 \%$ ao ano. ${ }^{23}$

O total dos financiamentos proporcionados pelo BNDE entre 1952 e $1960^{24}$ e os volumes alocados pela União à educação e saúde podem ser visualizados na Tabela 5 a seguir.

(22) Bieslchowsky (2000, p. 433-434) assinala o momento tardio no qual a "questão das reformas sociais" foi incorporada ao debate intelectual: "A impressão inicial reforçou-se ao longo do trabalho: parece que, dadas as características da estrutura política e social então existente no país - isto é, o quadro institucional, as estruturas de propriedade e dominação etc. - o projeto de vanguarda que se afigurou como historicamente viável era o da realização de uma industrialização, pura e simplesmente" (...) "Nessa última fase [final dos anos 50 e início dos anos 60], quando o pensamento desenvolvimentista dava mostras de exaustão, começaram a surgir as primeiras formulações analíticas visando à defesa de um capitalismo com maior justiça social e com redistribuição da renda e da propriedade" - infelizmente abortadas pelo golpe militar.

(23) A lei de criação do BNDE (Lei n. 1.268, de 20/06/1952) previa ainda como fontes de recursos: "a) até 4\% do valor total dos depósitos das Caixas Econômicas Federais; b) até 25\% das reservas técnicas que as Companhias de Seguro e de Capitalização deviam constituir anualmente; c) até 3\% da receita anual dos órgãos de Previdência Social, excluída a quota que cabia à União" (Maia (1986, p. 67). Em 1956, novo dispositivo legal excluiu a Previdência Social dessa contribuição compulsória.

(24) Deve-se ressaltar que no total financiado pelo BNDE incluíam-se os empréstimos reembolsáveis (cuja participação no total varia de $54,4 \%$ a $97,1 \%$ ), a participação societária (com predomínio das empresas estatais e que absorve de $1,6 \%$ a $42,2 \%$ dos recursos do BNDE) e as inversões diretas do BNDE (1,3\% a 3,9\% do total dos financiamentos).

Economia e Sociedade, Campinas, v. 19, n. 3 (40), p. 529-556, dez. 2010. 
Tabela 5

Total financiado pelo BNDE e

Gasto da União com Educação e Saúde - 1952/60

\begin{tabular}{lcrcr}
\hline Ano & $\begin{array}{c}\text { Total financiado } \\
\text { pelo BNDE (A) }\end{array}$ & $\begin{array}{c}\text { Gasto com } \\
\text { Saúde (B) }\end{array}$ & $\begin{array}{c}\text { Gasto com } \\
\text { Educação (C) }\end{array}$ & $\begin{array}{c}\text { A/(B+C) } \\
\%\end{array}$ \\
\hline 1952 & $1.181,0$ & $1.318,0$ & $2.000 .000)$ \\
1953 & $1.485,6$ & -- & -- & $35,1 \%$ \\
1954 & $2.974,3$ & -- & $3.703,3$ & \\
1955 & $2.592,4$ & $3.024,4$ & $4.004,9$ & $36,9 \%$ \\
1956 & $6.625,0$ & -- & $5.359,0$ & \\
1957 & $8.455,2$ & $4.401,3$ & $7.940,7$ & $68,5 \%$ \\
1958 & $12.180,7$ & -- & $11.515,9$ & \\
1959 & $10.432,0$ & -- & $15.790,8$ & \\
1960 & $13.737,8$ & $11.456,6$ & $20.171,8$ & $43,4 \%$ \\
\hline
\end{tabular}

Fontes dos dados primários: Maia (1986), Brasil. Ministério da Fazenda. Balanço Geral da União (Vários anos). Brasil. Ministério da Educação e Cultura (1957, 1958, 1959 e 1960).

Ainda que tomada isoladamente tal informação, parece inegável sua eloquência em demonstrar o novo direcionamento dado às funções estatais, com a maior importância assumida pelo Estado no campo econômico. Assim, apenas os empréstimos do BNDE - desconsiderando-se, portanto, todo o conjunto de incentivos fiscais e subsídios espalhados em outros órgãos da administração pública: Banco do Brasil, CEXIM (CACEX), etc. - somavam volume equivalente a nunca menos de 1/3 dos gastos totais com educação e saúde pela União nos anos para os quais se dispõe das informações. Para os anos de 1957 e 1960, o volume de empréstimos do BNDE revelou-se superior ao total despendido pelo Governo Federal com saúde e equivalente a $68,5 \%$ e $43,4 \%$ das despesas totais com educação e saúde.

A somar-se a estas considerações, há a constatação do significativo percentual de subsídio implícito em tais empréstimos. Um estudo de caso realizado por Maia demonstra um subsídio de $43 \%$ da dívida contraída por uma empresa em 1958 e paga até 1964 (Maia, 1986, p. 139-148).

\section{Considerações finais}

Ainda que limitada e mesmo condicionada pelo quadro econômico, a dinâmica da política social se encontra essencialmente relacionada a todo debate político/ideológico que se trave numa sociedade. Os limites máximo e mínimo nos quais pode se mover o montante alocado de recursos para a área social depende crucialmente do nível de desenvolvimento econômico alcançado por um país. A partir daí, no entanto, se abre largo espectro factível para que os fatores políticos e 
o debate ideológico possam dimensionar concretamente a magnitude e as características do gasto social.

Dentre estes fatores políticos/ideológicos, o conceito-chave a assomar é o de cidadania. A abrangência e a penetração que possam ter esta noção jurídica/política na vida institucional de uma nação revela-se, de acordo com a experiência histórica de inúmeros países, até mesmo do Brasil, como de fundamental importância para o dimensionamento e a qualidade da política social.

Assim, as inferências possíveis a respeito das possibilidades mais amplas ou estreitas de organização da sociedade civil em todas as suas manifestações, notadamente o movimento sindical, para influenciar decisivamente a política governamental, constituem um dos eixos básicos deste artigo. Não houve no período populista, com exceção de seus anos derradeiros, condições para que um movimento classista e autônomo por parte dos trabalhadores pudesse pressionar mais decididamente por alterações expressivas na política pública, direcionando-a mais resolutamente para o atendimento das necessidades da maioria da população mediante a ênfase na política social. Conseguiu-se, quando muito, operar uma segmentação da política social de acordo com o poder de pressão distinto de cada grupo social.

As condições restritas nas quais se moveu o movimento sindical, dadas principalmente pelo contexto do corporativismo, e as peculiaridades do processo político no Brasil populista permitiu a consolidação de uma subespécie de cidadania que Wanderley Guilherme dos Santos (1979) denominou "cidadania regulada".

A característica fundamental da cidadania regulada é seu caráter excludente e discriminatório, pautando-se essencialmente pela incorporação controlada de grupos de trabalhadores aos direitos sociais, incluindo-se aí, de forma privilegiada, o seguro social e o atendimento médico individualizado. Aos segmentos de trabalhadores mais mobilizados garantiram-se tratamento e inserção diferenciados nas políticas públicas. Tal fato colaborou sobremaneira para que a própria pauta de reivindicações dos trabalhadores caracterizasse-se antes pela segmentação que pela definição de propostas mais universalistas quanto à política social.

A disseminação e a hegemonia da ideologia desenvolvimentista adquiriram igual relevância para o período populista, notadamente na fase democrática.

A instalação do jogo democrático, conquanto sujeito a várias restrições, a partir de 1946, provocou inequívoca mudança ascendente no patamar do gasto social, tanto como porcentagem do dispêndio público global como em relação à participação no produto interno bruto. No entanto, a proeminência da ideologia 
desenvolvimentista atenuou a influência favorável do contexto político mais amplo na alocação de recursos para a área social.

O desenvolvimentismo permitiu explicitar, mesmo - ou melhor, sobretudo - para as forças políticas mais progressistas, a necessidade de equacionar-se, antes de tudo, o problema do subdesenvolvimento. Estabeleceu-se, assim, um ponto de vista no qual os recursos alocados para a área social foram percebidos como concorrentes aos investimentos diretamente produtivos. Em nome de um futuro mais benfazejo a todos, impunham-se sacrifícios presentes.

As decorrências de tal linha de pensamento não poderiam ser distintas à de uma restrita ênfase na alocação de recursos para a área social quando da confecção do orçamento. E mais ainda, permitiu viabilizar a utilização dos recursos do sistema previdenciário para o esforço de incrementar a taxa de investimento. $\mathrm{O}$ ponto a sublinhar refere-se ao crescimento mais intenso dos gastos públicos com a área social justamente durante um governo cuja ênfase retórica recai sobre o liberalismo, conquanto sua postura relativamente a outros aspectos de uma política redistributiva - regulação do conflito capital-trabalho e política de salário mínimo - apontassem em sentido oposto.

Em parte, a expansão dos gastos com educação pode ser explicada pelas novas normas instituídas com a Constituição de 1946 (Brasil, 1948), mediante a qual ficava estabelecido que

anualmente, a União aplicará nunca menos de dez por cento, e os Estados, o Distrito Federal e os Municípios nunca menos de vinte por cento da renda resultante dos impostos na manutenção e desenvolvimento do ensino (artigo 169).

Todavia, considerando-se a postura nitidamente conservadora do Governo Dutra e o fato de que a Constituição de 1946 não estabeleceu qualquer obrigatoriedade de dispêndio com a área de saúde, é razoável supor que, se dependesse apenas do Executivo, muito provavelmente os gastos sociais não terse-iam elevado na proporção assinalada acima. Tratou-se, portanto, de uma decisão afeta ao conjunto das forças políticas então hegemônicas, temporariamente mais inclinadas ao liberalismo. A ascensão e consolidação da hegemonia dos intervencionistas/desenvolvimentistas significaram, na prática, um arrefecimento da taxa de acréscimo do gasto social.

A ironia da história fez com que, no Brasil das décadas de 1940 e 1950, os grupos mais conservadores politicamente fossem os principais responsáveis pela defesa da política social - estivessem sinceramente ou não envolvidos nessa defesa. Coube aos "progressistas", identificados aqui aos desenvolvimentistas, o papel de assentar uma visão alternativa de Estado centrada no campo econômico. Aos grupos mais à esquerda no espectro político interessava antes a consolidação de uma política vigorosa de desenvolvimento econômico que medidas 
relacionadas a uma política social mais incisiva e abrangente. Tal orientação básica alterou-se apenas nos anos finais do populismo.

A vitória do pensamento e das forças políticas "progressistas" colaborou para consolidar a política social em posição subalterna no seio das políticas públicas. As peculiaridades estruturais conformadoras do desenvolvimento econômico e a ideologia desenvolvimentista - esta última, causa e consequência dessa dinâmica econômica particular- permitiu a inversão dos papéis tipicamente observados entre os grupos políticos mais conservadores e progressistas em outros países, influindo decisivamente na alocação de recursos para a área social.

\section{Referências bibliográficas}

ABRANCHES, Sérgio H. et al. Os despossuídos - crescimento e pobreza no país do milagre. Rio de Janeiro: Jorge Zahar, 2000.

ALMINO, João. Os democratas autoritários: liberdades individuais, de associação política e sindical na Constituição de 1946. São Paulo: Brasiliense, 1980.

BIELSCHOWSKY, Ricardo. Pensamento econômico brasileiro: o ciclo ideológico do desenvolvimentismo. 4. ed. Rio de Janeiro: Contraponto, 2000.

BIERRENBACH, Maria Inês Rocha de Sousa. Política e planejamento social - Brasil: 1956-1978. 3. ed. São Paulo: Cortez, 2000.

BRAGA, José Carlos de Souza; PAULA, Sérgio Góes de. Saúde e previdência: estudos de política social. 2. ed. São Paulo: Hucitec, 1986.

BRASIL. FIBGE. Anuário Estatístico do Brasil. Rio de Janeiro. Vários anos.

. Sinopse estatística do Brasil. Rio de Janeiro: IBGE, 1940.

1941.

Repertório estatístico do Brasil - Situação Social No 1. Rio de Janeiro: IBGE, . O mundo em números. Rio de Janeiro: IBGE, 1957.

. O Brasil em números - Apêndice do Anuário Estatístico do Brasil-1960. Rio de Janeiro: IBGE, 1960.

. Indicadores sociais: tabelas selecionadas. Rio de Janeiro: IBGE, 1984. 2 v.

. Séries estatísticas retrospectivas. Rio de Janeiro: IBGE, 1986. 3 v.

- Estatísticas históricas do Brasil: séries econômicas, demográficas e sociais de 1550 a 1988. 2. ed. rev. e atual. do volume 3 de Séries estatísticas retrospectivas. Rio de Janeiro: IBGE, 1990.

BRASIL. LEIS, DECRETOS. Constituição da República dos Estados Unidos do Brasil 1946. São Paulo: Edição Saraiva, 1948.

BRASIL. MINISTÉRIO DA EDUCAÇÄO E CULTURA. Estatísticas das despesas com o ensino e a cultura - 1956. Rio de Janeiro: Serviço de Estatística da Educação e Cultura, 1957. 
Julio Manuel Pires

BRASIL. MINISTÉRIO DA EDUCAÇÄO E CULTURA. Estatísticas das despesas com o ensino e a cultura - 1957/58. Rio de Janeiro: Serviço de Estatística da Educação e Cultura, 1958.

Estatísticas das despesas com o ensino e a cultura - 1958/59. Rio de Janeiro: Serviço de Estatística da Educação e Cultura, 1959.

Estatísticas das despesas com o ensino e a cultura - 1959/60. Rio de Janeiro: Serviço de Estatística da Educação e Cultura, 1960.

BRASIL. MINISTÉRIO DA FAZENDA. Balanço Geral da União. Rio de Janeiro. Vários anos.

$\overline{\text { números. }} \cdot$

Boletim do Conselho Técnico de Economia e Finanças. Rio de Janeiro. Vários

. Revista de Finanças Públicas. Rio de Janeiro. Vários números.

Finanças do Brasil: orçamentos e balanços - Estados e Municípios: quinquênio 1943-1947. Rio de Janeiro, 1949. v. XVII.

- Finanças do Brasil: receita e despesa - União, Estados e Municípios, exercícios de 1941/1950. Rio de Janeiro, 1952. v. XVIII.

BRASIL. PRESIDÊNCIA DA REPÚBLICA. Plano SALTE. Rio de Janeiro: Departamento de Imprensa Nacional, 1950.

CARONE, Edgard. A república liberal - I (Instituições e classes sociais). São Paulo: Difel, 1985.

CIGNOLLI, Alberto. Estado e força de trabalho: introdução à política social no Brasil. São Paulo: Brasiliense, 2001.

COHN, Amélia. Previdência social e processo político no Brasil. São Paulo: Moderna, 2001.

COUTINHO, Maurício C.; SALM, Claúdio. Previdência social. In: BACHA, Edmar Lisboa; KLEIN, Herbert S. (Org.). A transição incompleta: Brasil desde 1945. Rio de Janeiro: Paz e Terra, 1986. v. 2, p. 211-243.

CUNHA, Luís Antônio. Educação e desenvolvimento social no Brasil. Rio de Janeiro: Francisco Alves, 1975.

DEMO, Pedro. Política social nas décadas de 60 e 70. Fortaleza: Edições UFC, 1981.

DRAIBE, Sônia Miriam. Rumos e metamorfoses: um estudo sobre a constituição do Estado e as alternativas da industrialização no Brasil, 1930-1960. Rio de Janeiro: Paz e Terra, 1985.

FISCHLOWITZ, Estanislau. Previdência Social. Rio de Janeiro: DASP - Serviço de documentação, 1955. (Ensaios de Administração, n. 4).

FONSECA, Pedro Cezar Dutra. Vargas: o capitalismo em construção - 1906-1954. São Paulo: Brasiliense, 1989.

FUNDAÇÃO GETÚLIO VARGAS. A Previdência Social no Brasil e no estrangeiro. Rio de Janeiro. 1950. 
GIACOMONI, James. Orçamento público. 2. ed. São Paulo: Atlas, 1986.

GONÇALVES, Ernesto Lima. Avaliação crítica do sistema assistencial brasileiro. In: GONÇALVES, Ernesto Lima (Org.). Administração de saúde no Brasil. São Paulo: Pioneira, 1982. p. 138-162.

GOUGH, Ian. Gastos del Estado en el capitalismo avanzado. In: SONNTAG, Heinz Rudolf; VALECILLOS, Héctor. El Estado en el capitalismo contemporáneo. 9. ed. México: Siglo Veintiuno Editores, 1990. p. 224-302.

HADDAD, Claúdio L. S. O crescimento do produto real do Brasil - 1900-1947. Rio de Janeiro: FGV, 1978.

IANNI, Octavio. O colapso do populismo no Brasil. 4. ed. rev. Rio de Janeiro: Civilização Brasileira, 1978.

JAGUARIBE, Hélio et al. Brasil, 2000 - para um novo pacto social. Rio de Janeiro: Paz e Terra, 1986.

Brasil: reforma ou caos. Rio de Janeiro: Paz e Terra, 1989.

LIMA, José Luiz. Estado e setor elétrico no Brasil: do código de águas à crise dos anos 80 - 1934-1984. Tese (Doutorado em Economia)-FEA-USP, São Paulo, 1989.

MACEDO, Ésio de F. O serviço de saúde pública à luz da geografia financeira. Revista de Finanças Públicas, p. 17-21, set./out. 1960.

A situação municipal em 1959 à luz da geografia financeira. Revista de Finanças Públicas, p. 23-33, abr./mai./jun. 1961.

MAIA, Rosane de Almeida. Estado e industrialização no Brasil: estudo dos incentivos ao setor privado nos quadros do Programa de Metas do Governo Kubitschek. Dissertação (Mestrado)-FEA-USP, São Paulo, 1986. Mimeografado.

MALlOY, James M. A política da Previdência Social no Brasil. Rio de Janeiro: Graal, 1986.

MELLO, Carlos Gentile de. Saúde e assistência médica no Brasil. São Paulo: CEBESHucitec, 1977.

OLIVEIRA, Jaime A. A.; TEIXEIRA, Sônia M. Fleury. (Im)Previdência Social: 60 anos de história da Previdência no Brasil. Petrópolis: Vozes/ABRASCO, 1986.

PEDRO, Alim. O seguro social; A indústria brasileira; $O$ instituto dos industriários. Rio de Janeiro: IAPI , 1950.

POSSAS, Cristina de Albuquerque. Saúde e trabalho, a crise da previdência social. Rio de Janeiro: Hucitec, 2001.

ROMANELLI, Otaíza. História da educação no Brasil (1930-1973). 30. ed. Petrópolis: Vozes, 2000.

SANTOS, Wanderley Guilherme dos. Cidadania e justiça: a política social na ordem brasileira. Rio de Janeiro: Campus, 1979.

SINGER, Paul. A crise do "milagre". 8. ed. Rio de Janeiro: Paz e Terra, 1989. 
Julio Manuel Pires

VIANA, Arizio de. Orçamento brasileiro. 2. ed. Rio de Janeiro: Edições Financeira, 1950.

VIANNA, Sérgio Besserman. A política econômica no segundo Governo Vargas (19511954). Rio de Janeiro: BNDES, 1987.

VIANNA, Maria Lúcia T. Werneck; SILVA, Beatriz Azeredo da. Interpretação e avaliação da política social no Brasil: uma bibliografia comentada. In: MPAS/CEPAL. A política social em tempo de crise: articulação institucional e descentralização. Brasília, 1989. v. III, p. 109-275.

VIEIRA, Pedro José M. Resumo histórico da assistência social no Brasil. Rio de Janeiro: FLBA, 1986. 